\title{
Populisme, Pilkada dan Masa Depan Demokrasi
}

\author{
Populism, the Pilkada and the Future of Democracy \\ Peter Tan \\ Mahasiswa Pascasarjana STF Driyarkara \\ E-mail: tanpeter997@yahoo.com
}

\begin{abstract}
Populism has risen to become a contemporary political phenomenon at both the global, national and local levels. Electoral contestations, including the election of district heads or "Pilkada", were infiltrated by populist political practices. In this paper, I mostly use the perspective of political philosophy on populism. The main thesis of this paper is that populism threatens the existence of democracy when populist actors and politicians exploit the ethnic and religious sentiments of the voters, or exploit the people's vulnerabilities as mere populist narratives and rhetoric to win the electoral support. On the other hand, the discourse on antagonism in left populism is able to make a positive contribution to democracy as long as it is always placed within the framework of an antagonistic democratic discourse. Within the framework of antagonistic democracy, left populism consistently exposes the depravity of power, constructs the "people" as a group that opposes the oligarchic and neoliberal elites, and struggles for the right to social justice of the oppressed. This politico-philosophical analysis of populism is relevant in reflecting on the moments of electoral contestations such as the election of district heads (Pilkada) and on the fight for a better future of democracy.
\end{abstract}

Keywords: Populism, antagonistic democracy, politics, people, oligarchy, Pilkada

\begin{abstract}
Abstraksi
Populisme telah bangkit menjadi fenomena politik kontemporer baik pada tataran global, nasional maupun lokal. Kontestasi-kontestasi elektoral, termasuk Pilkada, banyak disusupi oleh praktik politik populis. Dalam tulisan ini, saya lebih banyak memakai perspektif filsafat politik tentang populisme. Tesis dasar tulisan ini ialah populisme mengancam eksistensi demokrasi manakala para aktor populis gemar mengeksploitasi sentimen etnis dan agama masyarakat pemilih, atau mengeksploitasi luka-luka rakyat hanya sebagai narasi dan retorika populis belaka untuk merebut dukungan elektoral. Sebaliknya, diskursus antagonisme dalam populisme kiri mampu memberikan sumbangan positip bagi demokrasi sejauh selalu ditempatkan dalam kerangka wacana demokrasi antagonistik. Dalam kerangka demokrasi antagonistik, populisme kiri secara konsisten membuka kebobrokan kekuasaan, mengkonstruksi "rakyat" sebagai kelompok yang melawan elite-elite oligarkis dan neoliberal, dan memperjuangkan hak rakyat tertindas akan keadilan sosial. Analisis filsafat politik tentang populisme ini relevan dalam merefleksikan tentang momen konstestasi elektoral seperti Pilkada dan tentang bagaimana memperjuangkan masa depan demokrasi yang lebih baik.
\end{abstract}

Kata Kunci: Populisme, demokrasi antagonistik, politik, rakyat, oligarki, pilkada

\section{Pendahuluan}

A spectre is haunting the worldpopulism- Seekor hantu sedang memburu dunia, populisme namanya. Seruan terkenal
Marx dan Engel ini dipakai oleh Ghita Ionescu dan Ernest Gellner untuk membuka karya klasik mereka tentang populisme (Albertazzi dan McDonell, 2008: 1). Ungkapan ini tak hanya menggambarkan 
kebangkitan populisme di Eropa Barat pada akhir tahun 1960-an, melainkan juga di banyak tempat di dunia seperti di Amerika Utara, Amerika Latin, Rusia, Eropa Timur dan Afrika. Di abad ke-21, hantu ini dan terornya semakin nyata. Kemenangan Donald Trump pada pemilihan Presiden Amerika Serikat tahun 2016 yang diraih lewat pembengkakan konservatisme ras kulit putih dan sentimen kebencian terhadap minoritas, atau permainan isu-isu etnis dan agama di Indonesia dalam Pemilihan Presiden 2014 dan 2019, serta pilgub DKI 2017, sering disebut sebagai simptom kebangkitan populisme. Sekurangkurangnya melalui beberapa fakta itu, kita menyaksikan populisme telah memasuki kontestasi politik baik pada tataran global, nasional maupun lokal.

Populisme, menyitir Ernesto Laclau dalam Politics and Ideology in Marxist Theory, adalah sebuah konsep yang sukar dipahami dan membingungkan (Laclau, 1977: 143). Di Indonesia, topik ini terbilang baru dalam kajian ilmiah meskipun ada banyak kejadian politik di tanah air yang bisa disebut sebagai simptom kebangkitan populisme. Secara intuitif kita bisa membaptis sebuah ideologi, gerakan, kejadian, kampanye dan iklan politik sebagai "populis", tapi terganjal kesulitan saat menerjemahkan intuisi itu ke dalam sebuah konsep. Margerth Canovan pernah menyebut populisme sebagai "suatu bayangan yang dicetak demokrasi itu sendiri". Populisme lahir dari krisis demokrasi. Benjamin Arditi tak setuju dengan Canovan. Arditi melihat populisme sebagai a spectre of democracy (hantu demokrasi) ketimbang bayangan demokrasi (Panizza, 2005: 72).

Terlepas dari polemik itu, ada beberapa fakta tak terbantahkan yang patut menjadi pusat perhatian dalam tulisan ini. Pertama, kebangkitan populisme pada mulanya hanyalah simptom dari krisis besar politik dan demokrasi. Dia misalnya merupakan reaksi terhadap kegagalan partai tradisional di mata para pemilih (voters) untuk merespons secara memadai serangkaian isu dan fenomena perubahan sosial seperti globalisasi ekonomi dan budaya, kemunduran ideologi politik, menjamurnya elit-elit korup, oligarki yang menguat dan malaise politik. Keadaan ini memicu sikap anti-politik. Publik menganggap politik terlalu berbelit-belit dan para politisi identik dengan preman dan pemeras berbaju partai. Pandangan ini mempengaruhi perilaku pemilih dalam pemilu. Publik yang kecewa tidak mau repot-repot berpartisipasi secara rasional. Dalam situasi ini, munculnya aktor populis kanan yang pandai mengaduk-aduk emosi dengan isu-isu sentimental (ras, agama, gender, anti-asing, dll), minus akal sehat dan rasionalitas, dianggap mampu menyediakan alternatif radikal di tengah krisis tersebut.

Kedua, populisme terkait erat dengan demokrasi. Baik demokrasi maupun populisme sama-sama berakar solid pada rakyat dan sama-sama menunjukkan kepentingan rakyat sebagai tujuan tertinggi. Di sini, secara empiris, populisme sebaiknya dipahami dalam konteks demokrasi liberal, bukan demokrasi per se atau model-model demokrasi lainnya (Mudde dan Kaltwasser 2017: 1). Sebab fakta menunjukkan, semua aktor populis bergerak dalam sistem demokrasi atau politik yang sedang mewujudkan cita-cita liberal dan demokratis.

Ketiga, populisme membuktikan dirinya lebih dinamis, fleksibel dan berhasil ketimbang apa yang dipikirkan banyak orang. Dari pengalaman politik abad ke-21, kesuksesan populisme ini tidak terlepas dari propaganda politik yang sering dimainkan para aktor politis. Atas nama rakyat (people), the spectre (hantu) populisme dan para aktor populis terus mempropagandakan perlawanan terhadap the sceptre (kekuasaan) 
yang korup, oligarkis dan menindas rakyat yang lemah. Bukan hanya mengkonstruksi mode of identification (Mouffe) atau antagonisme, para aktor populis ini juga secara terang-terangan mengatakan bahwa mereka membenci korupsi, oligarki, neoliberalisme, globalisasi, kekuasaan asing, dan elitisme serentak mencintai rakyat yang tertindas atau berjuang demi nasib mereka. Akan tetapi, faktanya tidak demikian. Sebagaimana Hadiz dan Robison, kebangkitan populisme tidak berarti oligarki berakhir (Hadiz dan Robison, 2017: 489). Retorika populis justru sering menjadi bagian dari usaha memperebutkan kekuasaan oligarkis itu sendiri. Gagasan populis menjadi kendaraan bagi lahirnya pemain baru di dalam oligarki. Di sini, kiri atau kanan dalam populisme telah kehilangan batasnya masing-masing.

Analisis tentang populisme sangat relevan dalam setiap momen kontestasi elektoral, termasuk pilkada. Sehubungan dengan diskursus mengenai pilkada, gagasan tentang populisme dan relasinya dengan demokrasi yang akan diuraikan dalam tulisan ini dapat menjadi sebuah paradigma kritis dan payung refleksi dari sudut pandang filsafat politik. Untuk maksud itu, penulis merangkai tulisan ini dalam beberapa bagian. Pertama, penulis akan menguraikan pemahaman populisme berdasarkan salah satu model interpretasi yaitu pembacaan simptomatik. Kedua, penulis akan menguraikan populisme sebagai ancaman dan hantu bagi keberlangsungan demokrasi. Ketiga, penulis akan melanjutkan pembahasan dengan menguraikan pilkada dalam hubungannya dengan populisme. Keempat, pembahasan dilanjutkan dengan uraian tentang masa depan demokrasi. Tulisan ini akan ditutup dengan sejumlah kesimpulan yang perlu.

\section{Memahami Populisme: Pembacaan Simptomatik}

Sebagaimana pengakuan Laclau di atas, populisme adalah sebuah konsep yang sangat luas, sukar didefinisikan dan membingungkan. Ada berbagai macam pendekatan yang dipakai untuk menganalisis konsep populisme. Cas Mudde dan Cristobal Rovira Kaltwasser merangkumnya ke dalam beberapa pendekatan (Mudde dan Kaltwasser, 2017: 3). Pertama, pendekatan keagenan populer yang menekankan populisme sebagai kekuatan untuk memobilisasi massa dalam gerakan-gerakan sosial dan kekuatan mengkonstruksi model komunitarian demokrasi. Kedua, pendekatan filsafat politik Laclau dan Mouffe yang disebut juga sebagai studi kritis. Pendekatan ini melihat populisme secara positip sebagai kekuatan emansipatoris dan sebaliknya memandang demokrasi liberal bermasalah. Ketiga, pendekatan yang melihat populisme sebagai gaya politik praktis yang dimainkan oleh sejumlah politisi dan partai untuk memobilisasi dukungan elektoral massa. Keempat, pendekatan ideasional yang melihat populisme sebagai konsepsi politik yang menekankan konflik antara massa yang dipenuhi dengan kebajikan moral dan elit politik yang korup. Beberapa pendekatan ini akan muncul dalam uraian ini.

Fokus saya pada bagian ini adalah melakukan pembacaan simptomatik terhadap populisme. Populisme pertamatama dipahami sebagai "simptom" (gejala) ketidakberesan dalam demokrasi. Karena itu, pembacaan simptomatik ini mutlak memerlukan pendekatan filsafat politik atau studi kritis Laclau dan pendekatan ideasional di atas. Di satu sisi, perspektif ini akan menempatkan populisme sebagai sebuah kekuatan luhur dalam demokrasi untuk melawan berbagai jenis ketimpangan politik, atau sering disebut populisme kiri. Seperti akan dijelaskan di bagian akhir 
tulisan ini, dalam hubungan dengan demokrasi antagonistik, populisme kiri menyokong demokrasi manakala dia secara konsisten merumuskan antagonisme masyarakat melawan sistem ekonomi politik oligarkis dan neo-liberal. Di sisi lain, kita menyaksikan fakta bahwa seringkali populisme dijadikan sekadar retorika atau candu massa, karena pada akhirnya aktoraktor populis yang gemar menarasikan lukaluka rakyat itu menjadi pemain-pemain baru dalam kekuasaan oligarkis. Maka, untuk memahami bagaimana populisme bekerja dan bagaimana para aktor populis mengeksploitasi gagasan-gagasan populis demi mendapatkan dukungan elektoral, interpretasi simptomatik ini mungkin sangat berguna.

Pendekatan simptomatik menekankan "people" (rakyat) sebagai political actor (aktor politik) dalam pertarungannya dengan the other (elit). Siapakah rakyat dan elit tersebut? Laclau dalam filsafat politiknya mendefinisikan people (rakyat) sebagai "empty signifier" (penanda kosong) yang membuat populisme sebagai ideologi dan fenomena politik yang kuat. Sebagai penanda kosong,"people" adalah produk identifikasi dan konstruksi (Mudde dan Kaltwasser, 2017: 9-11). Dalam populisme, rakyat dipahami sebagai "rakyat yang berdaulat" namun tidak diwakili oleh elit dalam kekuasaan sehingga mereka harus memberontak dan bersikap kritis terhadap kemapanan. Rakyat juga dipahami sebagai "masyarakat biasa" yang membela martabat dari kelompok yang keberadaannya secara objektif dan subjektif dianggap telah dikucilkan oleh kekuasaan sehubungan dengan status ekonomi dan budaya mereka. Oleh karena itu, inferioritas budaya dan ekonomi ini sering dipakai oleh para aktor populis sebagai propaganda melawan elitelit politik yang sedang berkuasa. Rakyat juga dipahami sebagai "nation" (bangsa). Seorang aktor populis cenderung menyempitkan nation pada komunitas etnis atau agama tertentu. Karena itu, ras dan agama, sering menjadi alat propanda dalam populisme.

Di titik berseberangan, ada "elit-elit neo-liberal dan oligarkis" yang dikonstruksi oleh aktor populis sebagai musuh yang harus ditumbangkan. Elit didefinisikan dalam hubungannya dengan kekuasaan yaitu semua orang yang memegang kekuasaan atau berada di lingkaran kekuasaan entah politik, ekonomi, atau media (Mudde dan Kaltwasser, 2017: 12). Inti dari pandangan populis tentang elit ialah bahwa kekuatan sebenarnya tidak terletak pada pemimpin yang dipilih secara demokratis tetapi pada beberapa kekuatan bayangan yang terus memegang kekuasaan dan mengancam kedaulatan rakyat. Namun konstruksi tentang elit dalam populisme sering dimaksudkan untuk meloloskan propaganda bahwa para aktor populis yang dipilih secara demokratis mampu membereskan problem itu. Sejarawan Amerika, Richard Hofstadter menyebutnya sebagai "gaya politik paranoid" (Mudde dan Kaltwasser, 2017: 12).

Pendekatan antagonistik antara rakyat versus elit ini menempatkan populisme sebagai "anti-status quo discourse" (diskursus anti-status quo). Diskursus antistatus quo adalah sebuah diskursus yang menyederhanakan medan politik secara simbolik terbagi ke dalam dua kelas yang berhadap-hadapan: "the people" (rakyat tertindas, underdogs) dan the other (kelas elite demokrasi, penguasa/pemodal). Lugasnya, keduanya adalah konstruksi politik, bukan sekadar kategori sosial, yang secara simbolik terbangun dalam relasi antagonisme.

Antagonisme adalah mode of identification (modus identifikasi). Antagonisme memainkan peran sentral dalam proses dekonstruksi dan rekonstruksi identitas. Berseberangan dengan pendapat 
bahwa politik dapat direduksi motivasi individu atau dikendalikan kepentingan diri, kaum populis sungguh sadar, politik terbentuk dari pertarungan simbolik "kita" versus "mereka". Sebagaimana Laclau, pembentukan batas-batas politik antara kita versus mereka, kaum tertindas versus kaum berkuasa memerlukan bahwa partikularitaspartikularitas yang membentuk rakyat sebagai penanda menjadi elemen dalam jalinan kesetaraan/keadilan. Artinya, antagonisme memperkuat demokrasi karena menuntut adanya fusi ekuivalensi pelbagai partikularitas dan identitas berbeda sehingga membuka kanal partisipasi lebih luas.

Dari perspektif studi kritis Laclau, dimensi anti-status quo adalah dimensi paling substansial populisme. Dimensi ini mengharuskan populisme sebagai a full constitution of popular identity mewujudkan penaklukan politik terhadap the other yang dianggap mengeksploitasi dan menghalangi kehadiran penuh rakyat dalam sistem politik. The other, dalam oposisinya dengan the people, tereksplisitasi dalam term-term politik dan ekonomi atau kombinasi keduanya seperti oligarki, politisi, kelompok agama atau etnis dominan, plutokrasi, wakil rakyat, parlemen dan kelompok-kelompok lainnya. The other ini dipandang menghancurkan kesejahteraan rakyat.

Pertarungan diskursif antara "rakyat tertindas" dan "elit oligarkis" diubah oleh para aktor populis ke titik-titik yang lebih ekstrem yaitu pertarungan identitas antara "kita" vs "mereka". Di sini, aktor populis meleburkan identitasnya ke dalam identitas homogen yaitu "kita". Peleburan ini mau mengatakan tentang apa yang umumnya ingin didengar oleh rakyat tertindas yaitu aktor populis merasa senasib dan sepenanggungan dengan mereka. Pada saat yang sama, para aktor populis memposisikan diri pada titik pertentangan ekstrem dengan elit-elit oligarkis atau dengan isu-isu yang dianggap mengancam kesejahteraan rakyat seperti neoliberalisme, globalisasi, intervensi asing, imigran, korupsi, dan oligarki.

Berdasarkan wacana antagonistik itu, populisme adalah sebuah diskursus dikotomis di mana "rakyat" dihubungkan dengan "elite" dalam sebuah relasi antagonistik. Artinya "rakyat" secara diskursif dikonstruksikan sebagai suatu kelompok besar tak berkekuasaan dalam oposisinya dengan "elite" yang dikonstruksikan sebagai sekelompok kecil orang yang berkuasa (Agustin, 2020: 47). Karena itu, politik populis selalu merepresentasikan "rakyat" sebagai ekspresi kehendak umum melawan "elite" sebagai kelompok yang mengabaikan kehendak umum tersebut. Atau sebagaimana Mudde, populisme dapat juga dipahami sebagai "ideologi berpusat tipis yang menganggap masyarakat akhirnya dipisahkan menjadi kubu yang homogen dan antagonis, "rakyat yang bermoral" versus "elit yang korup", dan yang berpendapat bahwa politik harus menjadi volonte generale (kehendak umum rakyat)" (Mudde dan Kaltwasser, 2017: 6). Ideologi berpusat tipis menunjukkan kelenturan atau fleksibilitas populisme, yang berbeda dari ideologi-ideologi yang rigid seperti fasisme, sosialisme/komunisme, atau liberalisme. Kelenturan inilah yang menyebabkan populisme mudah berasimilasi atau akrab dengan ideologiideologi tersebut atau ideologi lainnya. Seorang fasis, liberal atau sosialis bisa menjadi seorang populis. Populisme dapat dengan mudah dijadikan sebagai kendaraan politik baik bagi pemimpin sosialis, liberal atau fasis.

Dalam relasi antagonistik itu, gagasan volonte generale turut mempertajam pertentangan antara rakyat dan elit politik. Rousseau membedakan volonte generale (kehendak umum) dan volonte de tous (kehendak semua). Sementara volonte de teus menunjuk kepada penjumlahan semua 
kepentingan warga pada saat-saat tertentu, volonte generale menunjuk pada kapasitas warga untuk terlibat dalam suatu kelompok yang memperjuangkan kepentingan mereka (Mudde dan Kaltwasser, 2017: 16). Dalam populisme, ide volonte generale ini tidak melibatkan proses rasional di ruang publik karena tujuannya hanyalah menggabungkan beberapa kepentingan massa yang berbeda sebagai kehendak umum dan segera mengidentifikasi musuh bersama. Dengan mengedepankan kehendak umum rakyat, tampak bahwa populisme mendukung demokratisasi atau kedaulatan rakyat karena berusaha mengubah rakyat sebagai subjek politik yang mampu menentang status quo elit-elit oligarki di pusat kekuasaan. Akan tetapi, problemnya selalu sama yaitu gagasan kehendak umum di tangan para aktor populis dapat dengan cepat bermetamorfosis menjadi dukungan terhadap otoritarianisme. Seorang pemimpin populis yang menganggap dirinya sebagai perwakilan kehendak umum akan dengan mudah membenarkan tirani mayoritas, penindasan terhadap minoritas, dan absolutisme negara demi kedaulatan rakyat.

Populisme karena itu adalah modus identifikasi yang bisa dipakai para aktor politik dalam ranah diskursif. Di dalamnya pemahaman akan kedaulatan rakyat dan akibat-akibatnya, konflik antara yang berkuasa dan yang tak berkekuasaan adalah elemen utama imajinasi politiknya. Pemahaman tentang rakyat berdaulat sebagai aktor politik dalam relasi antagonistiknya dengan tatanan teratur (negara, parlemen, DPR) telah dijejaki banyak penulis. Menurut Edwar Shils, populisme mengandung dua prinsip utama: sebagai supremasi kehendak rakyat dan sebagai hubungan langsung antara rakyat dan pemerintahan (Panizza, 2005: 2). Canovan bersama Laclau dan Worsley memakai pendekatan Marxian dalam memahami populisme. Populisme adalah wujud pembentukan identitas popular. Dalam masyarakat demokratik modern, dia dilihat sebagai perlawanan masyarakat marginal terhadap struktur kekuasaan represif dan ideologi dominan yang dipegang kelas elit atau the other (penguasa politik dan pemodal) dalam demokrasi.

Perspektif simptomatik ini serentak memperlihatkan krisis demokrasi sebagai radix (akar) kemunculan populisme. Populisme lahir sebagai kritik atas krisis sistem demokrasi representatif yang gagal menciptakan keadilan sosial dan gagal menjadi penyambung lidah rakyat yang diwakilinya (Madung, 2018). Selain krisis politik dan ekonomi, pemerintahan otoriter, kediktatoran militer dan pembaharuan institusi politik dapat menjadi akar kemunculan populisme. Di sini, populisme lebih dari sekadar respon terhadap kehancuran politik. Dia juga turut memperjuangkan nilai-nilai kesetaraan, bukan hirarki. Di situ, populisme berbeda dari fasisme (Albertazzi dan McDonell, 2008: 3).

Berdasarkan pendekatan simptomatik itu, dapat disimpulkan, populisme adalah sebuah ideologi yang mengkonfrontasikan masyarakat luhur dan homogen melawan serangkaian elit demokrasi yang berbahaya dan yang coba merampok kedaulatan rakyat atas hak-hak, nilai-nilai, kemakmuran, identitas dan kebebasan mereka. Dalam definisi ini, tampak bahwa populisme adalah sebuah ideologi, gagasan atau gerakan politik yang sangat memungkinkan ekuivalensi, kesetaraan dan keadilan. Populisme menjadi gerakan kiri yang berusaha mengembalikan kedaulatan rakyat sebagai pendulum dan titik pijak demokrasi. Lalu mengapa dia disebut sebagai a spectre of democracy (hantu demokrasi) jika dari sudut pandang tersebut dia tampak sebagai $a$ spectre of sceptre (hantu/musuh kekuasaan oligarkis neo-liberal)? 


\section{Hantu Demokrasi}

"Pemerintahan dari rakyat, oleh rakyat dan untuk rakyat". Ungkapan yang dicetuskan Abraham Lincoln pada tahun 1863 ini sering dipahami sebagai substansi demokrasi. Ungkapan ini diakui baik oleh kaum demokrat maupun kelompok populis. Dalam ungkapan itu, tersingkap hubungan intim demokrasi dan populisme, juga ketegangan antara keduanya. Hubungan itu terjadi manakala keduanya sama-sama berakar solid pada rakyat dan sama-sama menunjukkan kepentingan rakyat sebagai tujuan tertinggi. Seperti dalam demokrasi, koneksi dengan rakyat adalah inti dari populisme baik populisme kiri maupun kanan. Sebagaimana Peter Bloom, "politik modern tidak lagi tentang pertarungan antara sayap kiri dan kanan populisme, tetapi sebuah perlombaan mendefinisikan dan mengkonstruksi siapa "rakyat" dan apa yang mereka bisa perjuangkan atau capai bersama (Agustin, 2020: 46). Tentu saja, demokrasi seharusnya lebih luas daripada sekadar "kekuasaan atau kedaulatan rakyat". Akan tetapi, yang jelas, di mana rakyat tak berdaulat, di situ bisa dipastikan demokrasi telah mati. Jika kedaulatan rakyat menentukan kualitas demokrasi, frase Lincoln tersebut dapat diinterpretasi secara populis dan menjadi medan diskursif populisme.

Tapi, siapa rakyat? Dan bagaimana masyarakat yang terfragmentasi menjadi "satu" di dalam gerakan populis? Sebagaimana telah diuraikan di atas, rakyat dalam populisme bukan demos yaitu warga negara, yang memiliki hak-hak dan kewajiban-kewajiban, dengannya kedaulatan atau kebebasan dijalankan menurut batasbatas yang tersusun dalam suatu konstitusi. Rakyat juga bukan ethnos, mereka yang memiliki kesamaan darah, asal atau agama. Pemahaman tentang populus (rakyat) dalam populisme didasarkan pada pandangan kelas. Rakyat adalah kelas marginal, yang bekerja dan berjuang untuk bertahan hidup, yang dirampok kelompok elite, perusahaan, serta organisasi dan partai yang berafilisasi dengan kaum kapitalis, terlepas dari hak dan kewajiban konstitusional, agama atau etnisnya apa (Albertazzi dan McDonell, 2008: 3).

F.B. Hardiman memberi gagasan yang berbeda tentang rakyat. Menurutnya, sementara dalam demokrasi, rakyat adalah para warga negara, pekerja, asosiasiasosiasi, partai-partai, dan seterusnya atau demos, rakyat dalam populisme adalah massa tak terdiferensiasi. Karena itu, menurut F. B. Hardiman, populisme berbeda secara tajam dari demokrasi, meskipun populus dan demos sama-sama berarti rakyat (Hardiman, 2017: 6). Dengan kata lain, dalam demokrasi, rakyat adalah massa yang sadar kelas (Marx) atau rasional (tidak menabrak prosedur-prosedur legal). Sedangkan dalam populisme, rakyat mudah berubah menjadi $m o b$, gerombolan massa yang menabrak prosedur-prosedur legal, atau massa yang sentimental, bodoh dan bersikap seperti perempuan (Gustave Le Bon), mudah marah dan gampang dimanipulasi. Dalam populisme, demokrasi mudah berubah menjadi mobokrasi. Di sini, kata-kata Nietzsche relevan: "Massa adalah pertama, salinan kabur orang besar; kedua, pembangkangan melawan orang besar; ketiga, alat orang besar."

Berkaitan dengan dua pandangan berbeda ini, dapat disimpulkan bahwa, rakyat dalam populisme berkarakter ganda: mulia sekaligus mengerikan. Di satu sisi mereka adalah kelas marginal, orang-orang yang dirampok kelompok elite, atau singkatnya, kelompok yang memperjuangkan haknya akan keadilan sosial. Di sisi lain, mereka juga adalah gerombolan massa tak terdiferensiasi, mob yang mudah diprovokasi, atau gampang melabrak prosedur-prosedur demokratis atas 
nama suara-suara populis. Di situ, populisme tampil sebagai hantu yang mengancam demokrasi.

Dari posisi itu, kita melihat bahwa salah satu masalah serius yang turut menyebabkan populisme menjadi hantu demokrasi ialah antagonisme politik rentan disalahpahami sebagai formasi politik yang menuntut revolusi permanen. Di dalamnya penciptaan kembali identitas musuh seolaholah merupakan kondisi mutlak tindakan politik. Alhasil, populisme justru kontraproduktif. Di satu sisi, dia menghancurkan ilusi liberalisme tentang pluralisme tanpa antagonisme, tatanan sosial Hobbesian atau masyarakat tanpa kelas Marx. Di sisi lain, rakyat homogen atau massa tak terdiferensiasi dalam populisme itu sendiri juga merupakan sebuah ilusi, sama seperti masyarakat tanpa kelas Marx.

Dengan kata lain, bahaya populisme ialah perjuangan menentang bandit-bandit demokrasi sering terjadi melalui cara-cara irasional dan brutal seperti anti-pluralisme dan xenofobia picik. Sikap anti-pluralisme terungkap dalam keengganan berdebat secara rasional guna mencari solusi alternatif. Populisme berbahaya ketika perjuangan melawan ketidaksamaan sosial justru dilakukan dengan meniup politik identitas dan sentimen-sentimen picik antidemokrasi sehingga rentan melahirkan ketidakadilan sosial baru.

Persis itulah yang terjadi di Indonesia hari ini. Di negara ini, tameng terakhir sesudah kehilangan status ekonomi, ngawurnya akar budaya, lagi suara politiknya tak didengar adalah etnis dan agama. Maka, perlawanan terhadap hegemoni politik global, neo-liberalisme dan kebuasan kapitalisme nyaris mistik. Kita menolak mengajukan marxisme sebagai lawan filosofi yang sepadan dan malah menyiapkan ayat-ayat agama sebagai kontra moral baginya. Alhasil, sebagaimana Rocky Gerung, retorika dan hiruk-pikuk seputar isu neolib, hegemoni Barat atau kapitalisme merupakan refleks post-kolonial yang dangkal ketimbang hasil analisis intelektual yang dalam. Dengan demikian, perlawanan terhadap struktur-struktur politik dan ekonomi yang tak adil mudah disulap menjadi perkakas merebut kekuasaan. Hal itu kita saksikan dalam maraknya fenomena kebangkitan populisme kanan (mobilisasi massa dengan sentimen agama) di Indonesia dewasa ini. Para aktor populis kanan juga sering bersuara atas nama demokrasi tapi mereka sendiri melawan demokrasi dengan menginjak-injak hukum (prosedur-prosedur legal/undang-undang) dan tidak menghargai pluralisme.

Sebagaimana Otto Gusti, populisme sesungguhnya dapat menjadi kekuatan transformatif di Indonesia kalau dia benarbenar menjadi antagonisme kekuasaan oligarki yang kian menguat. Populisme gagal menjadi kekuatan antagonis dan emansipatoris karena dia turut melanggengkan kekuasaan oligarki (Madung, 2018). Lugasnya, di Indonesia, populisme kiri yang berperan merumuskan suara-suara warga yang tak terakomodasi dan antagonisme terhadap ketidakdilan sistem politik-ekonomi tidak pernah eksis. Yang eksis malah populisme kanan yang mudah diperalat para monster oligarki untuk merebut kekuasaan lewat pembengkakan sentimen-sentimen etnis dan agama. Gagal menjadi anti-status quo, populisme di Indonesia malah membentuk identitas final entah agama atau etnis yang mematikan energi antagonisme dalam demokrasi sehingga ikut melanggengkan kekuasaan elit-elit korup dan rakus.

Dapat dikatakan bahwa populisme gagal menjadi gerakan kiri yang menampilkan antagonisme fundamental terhadap kekuasaan oligarki yang menguat karena para pemimpin populis justru menyimpang ke kanan yaitu menjadi pemain baru dalam sistem oligarki yang sebelumnya 
mereka kutuk dalam propaganda mereka. Di Amerika, misalnya, kelompok kanan (republik) dengan Trump sebagai juru bicaranya sering mengkampanyekan retorika anti-globalisasi karena globalisasi dianggap merusak kedaulatan negara dan menjadi akar terorisme. Akan tetapi, ini hanyalah retorika populis untuk memperbesar sentimen ras kulit putih, sikap anti-Islam dan antiminoritas. Dalam kenyataan, kebijakankebijakan ekonomi luar negeri Trump sangat pro-kapitalisme. Selain itu, di Amerika Serikat, bukan saja kelompok sayap kiri melainkan juga kelompok sayap kanan mengkampanyekan sikap anti-kapitalis dan pengutamaan kepentingan umum di atas kepentingan privat sembari mengecam dengan keras elit politik yang bersekongkol dengan elit ekonomi. Akan tetapi, dalam kenyataan kritik ini tidak menunjukkan kelompok sayap kanan anti-kapitalis. Contohnya, banyak aktivis gerakan Tea Party di Amerika Serikat yang mengecam 'perselingkuhan' pebisnis-pebisnis besar dengan elit politik, tapi mereka sendiri adalah pembela kuat pasar bebas (Mudde dan Kaltwasser, 2017: 13).

Tidak hanya di Amerika Serikat. Argumen bahwa ide-ide populis gagal merepresentasikan gerakan kiri yang memperjuangkan keadilan dan malah menjadi kendaraan bagi para elit oligarkis baru merupakan sebuah argumen yang juga memiliki implikasi nyata di Indonesia. Sebagaimana menurut Hadiz dan Robison, meskipun populisme dapat mempengaruhi cara kerja tertentu dari politik oligarki di Indonesia, fakta yang terjadi ialah tidak adanya kontradiksi atau antagonisme yang tak terelakkan antara oligarki dan populisme. Sebaliknya, populisme "justru menjadi strategi untuk merebut dan mempertahankan kekuasaan oligarkis melalui persaingan demokratis" dalam pemilu (Hadiz dan Robison, 2017: 2). Jadi, alih-alih mengancam oligarki atau menjadi hantu kekuasaan, populisme di Indonesia justru menjadi instrumen merebut dan mempertahankan kekuasaan oligarkis. Dengan kata lain, populisme diambil alih oleh oligarki untuk semakin mengakarkan kepentingan mereka daripada sebagai gerakan kiri yang menentang proyek-proyek mereka.

Baru-baru ini, Ben Bland, seorang peneliti dari Lowy Institute-Australia menulis sebuah buku menarik tentang Jokowi. Bukunya berjudul, Man of Contradictions: Joko Widodo and the Struggle to Remake Indonesia (2020). Buku ini berbicara tentang kontradiksi gaya kepemimpinan politik Jokowi yang terjebak pada janji perbaikan demokrasi di satu sisi dan semakin menguatnya oligarki, otoritarianisme, dan politik dinasti di sisi lain. Dia berjanji untuk mengadvokasi toleransi dan pluralisme agama, tapi pada akhirnya terkooptasi di dalam cengkeraman kekuatan Islam konservatif. Tentang itu, Bland menulis:

The president is caught between the promise of democracy and the deep roots of authoritarianism in Indonesia. Jokowi has made economic growth the centrepiece of his administration. But he has been unable to square the desperate need for foreign investment with a culture of protectionism and scepticism towards economic liberalisation. He has attempted to advocate for religious tolerance and diversity. But he has ended up co-opting, or being coopted by, the forces of conservative Islam." (Bland, 2020: 13). 
Bland juga memperlihatkan bahwa pada awalnya Jokowi berjanji akan menjinakkan gurita oligarki yang telah menguasai Indonesia sejak Soeharto, yang melahap kekayaan dan sumber daya alam Indonesia, merusak birokrasi, dan menipu rakyat. Indonesia baru di bawah kepemimpinan Jokowi akan maju dengan perbaikan ekonomi yang memadai, demokrasi yang membaik, dan keadilan sosial bagi semua. Janji ini dipertegas lagi saat terpilih pada tahun 2019. Namun, menurut pengamatan Bland, semua janji Jokowi ini pudar di periode kedua kepemimpinannya karena Presiden yang disebut lahir dari rahim warga sipil di luar lingkaran oligarki itu justru telah menjadi sangat tertanam pada politik oligarkis (Bland, 2020: 11).

Menurut penelitian Bland, gaya blusukan Jokowi merupakan sebuah gaya yang sangat populis tapi sebetulnya tidak terlepas dari sokongan kekuatan oligarki di belakangnya. Bland (2020: 25) menulis:

Blusukan is emblematic of one key element in Jokowi's political rise: his talent for retail politics. The other element is his ability to corral local, and then national, elites behind him. The tycoons, party bosses, religious leaders, and generals have brought him the money, political connections, and

endorsements he has needed to capitalise on his connection to ordinary voters."

Blusukan adalah strategi politik Jokowi yang sederhana dan pragmatis. Akan tetapi, pemahaman yang sangat sederhana dan pragmatis tentang politik itu justru membuat kepemimpinan Jokowi disandera oleh oligarki, taipan, bos partai, konglomerat, dan pemimpin agama. Hal ini membuat janji keberpihakan pada rakyat kecil tidak sepenuhnya terlaksana, dan malah sebaliknya politik transaksional, korupsi, radikalisme agama dan perampasan hak warga semakin menjadi-jadi.

Kita melihat bahwa populisme pragmatis Jokowi telah bergerak dari demokrasi menuju otoritarianisme dan politik dinasti. Alih-alih memerangi korupsi, membersihkan birokrasi dan menjinakkan oligarki, kepemimpinan Jokowi justru memperkuat oligarki dan membangun dinasti politik baru. Menurut Bland, Jokowi secara tak sengaja menghidupkan kembali struktur pemerintahan Orde Baru, meraih kekuatan praktis apapun yang membantu mencapai tujuannya dan menjadi salah satu penjaga demokrasi yang buruk (Bland, 2020: 62). Gagasan kepemimpinan Jokowi yang terlampau populis dan pragmatis tentang demokrasi membuat kualitas demokrasi semakin menurun. Selama kepemimpinan Jokowi, demokrasi lebih dipahami sebagai "cara memberi manfaat ekonomi dan sosial" daripada menjunjung tinggi hak-hak sipil dan kebebasan (Bland, 2020: 68).

Pandangan populis, pragmatis dan iliberal tentang demokrasi tersebut membuat demokrasi semakin tergerus di bawah kekuasaan oligarki, konglomerasi, taipan politik, bos partai, dan elit-elit korup. Gagasan demokrasi yang iliberal ini juga menyebabkan kemerosotoan jaminan akan kebebasan sipil dan hak bersuara meskipun pemilihan umum atau pilkada yang kompetitif dilakukan secara rutin setiap lima tahun. Menguatnya politik Islam yang fundamentalistik dan anti-pluralis, penurunan kualitas demokrasi, ancaman terhadap kebebasan sipil, pelemahan KPK, represi terhadap oposisi, munculnya produk 
undang-undang kontroversial seperti UU Cipta Kerja, serta menguatnya oligarki dan politik dinasti menunjukkan bahwa seorang aktor populis telah bergeser dari gagasan populisme kiri kepada dukungan terhadap oligarki dan bahkan menjadi aktor baru di dalam politik oligarki.

\section{Pilkada dan Panggung Para Populis}

Sekurang-kurangnya, sejak kontestasi pilpres pada 2014 dan 2019 antara dua tokoh populis, Jokowi dan Prabowo, dan sejak pilkada DKI Jakarta 2017, kita menyaksikan bahwa populisme telah menjadi fenomena politik Indonesia baik di tingkat nasional maupun lokal. Dalam pilpres 2014 dan 2019, Jokowi dan Prabowo sama-sama mengklaim diri sebagai orang di luar politik. Mereka sama-sama berusaha menarik suara rakyat dengan memakai retorika nasionalisme dan keadilan sosial, serta mengkritisi elit politik yang kaya dan egois. Keduanya juga menyuarakan sentimen nasionalis dan anti-asing, meskipun Jokowi kelihatan lebih lunak dan Prabowo lebih keras (Hadiz dan Robison, 2017: 493). Sedangkan dalam pilkada Jakarta 2017, kita menyaksikan suatu gelombang besar populisme kanan yaitu permainan isu-isu identitas yang membangkitkan sentimen etnis dan agama sebagai taktik untuk merebut dukungan elektoral. Gelombang populisme ini diperbesar oleh penyebaran hoaks, ujaran kebencian dan propaganda politik pasca-kebenaran di media sosial. Beberapa fakta ini dapat menjadi preseden dari kenyataan bahwa populisme telah bergulir menjadi kendaraan politik dalam kontestasi elektoral di Indonesia, termasuk pilkada.

Sebagaimana telah dijelaskan sebelumnya, dalam hubungan dengan praktek demokrasi liberal, salah satu poin penting tentang populisme ialah populisme merupakan strategi yang dieksploitasi oleh para kandidat populis dan partainya untuk memobilisasi dukungan elektoral publik. Di sini, para kandidat populis itu menampilkan diri dalam banyak cara. Ada yang menampilkan diri sebagai pemimpin karismatik dan kuat, serta mampu mempertahankan koneksi mereka dengan rakyat kecil yang tertindas. Ada juga yang menunjukkan perilaku politik yang amatir dan tidak profesional, yang mencari perhatian media dan dukungan populer.

Sebagaimana Cas Mudde, dengan mengeksploitasi kemarahan, ketidaksantunan berbahasa, atau mengumbar ujaran kebencian dan pernyataan radikal yang mengundang kontroversi, politisi populis yang tidak profesional ini mampu menghadirkan diri tidak saja secara baru dan berbeda, tapi juga memproduksi kesan sebagai pemimpin yang berdiri bersama rakyat dalam menentang bandit-bandit oligarki (Mudde dan Kaltwasser, 2017: 4). Tentu saja, termasuk aktor populis amatir itu ialah para politisi yang gemar mengeksploitasi sentimen etnis dan agama untuk mendapatkan dukungan elektoral.

Karena itu, pilkada merupakan panggung bagi para populis. Demi merebut suara massa, setiap kandidat berusaha meyakinkan diri bahwa mereka adalah penyelamat yang berjuang bersama rakyat tertindas, melawan elit-elit korup dan kekuasaan oligarki yang menguat. Dengan kata lain, setiap aktor populis dalam pilkada sudah memperhitungkan dua hal berikut sebagai sarana memobilisasi dukungan elektoral yaitu pemisahan diri dari atau perlawanan terhadap elit oligarkis, dan koneksi dengan massa. Akan tetapi, sebagaimana Mudde (2017: 68), "pembelaan atas kedaulatan itu lebih sering hanya sebuah kepura-puraan sebab apa yang paling penting bagi para aktor populis ialah kepentingan mereka sendiri daripada advokasi suara perjuangan rakyat". 
Selain mengeksploitasi gagasan tentang keadilan sosial, perjuangan bersama rakyat tertindas dan perlawanan terhadap kekuasaan yang korup dan oligarkis, seorang aktor populis juga secara kreatif akan memobilisasi suara massa dalam pilkada dengan memanfaatkan beberapa strategi politik berikut yang dalam bahasa Mudde merupakan "perilaku politik yang amatir dan tidak profesional."

Pertama, berpolitik pasca-kebenaran. Pasca-kebenaran pada dasarnya adalah an emotional phenomenon (fenomena emosi), dan lenyapnya akal sehat untuk mencari kebenaran. Politik pasca-kebenaran dipahami sebagai zero-sum contest, pertengkaran emosi, daripada suatu kontes ide dan diskursus bermakna. Ilmu pengetahuan dan otoritas para ahli tidak dapat dipercaya dan kadang-kadang dianggap menjijikkan. Perdebatan publik dibingkai daya tarik emosi dan sentimen masyarakat pemilih, terlepas dari data, fakta bahkan pendapat para ahli independen. Sentimen mengalahkan argumen. Di sini, para aktor populis mengulang-ulang pernyataan palsu dalam sejumlah debat publik atau kampanye mereka, walaupun para pakar dan akademisi independen sudah membuktikan bahwa apa yang mereka katakan itu palsu dan keliru. Politik pascakebenaran ini didukung oleh teknologi informasi yang mengeksploitasi data dan media sosial, memanipulasi, menyebarkan hoaks, mempolarisasi dan menyerobot opini-opini publik.

Kedua, mengeksploitasi isu-isu etnis dan agama. Perhelatan pilkada tidak luput dari pemakaian isu-isu etnis dan agama yang sangat sensitif di ruang publik. Sebagaimana F. B. Hardiman (2017: 6), sementara di Eropa dan Amerika Serikat, populisme muncul dalam gagasan penguatan nasionalisme, di Indonesia populisme menyempit pada konservatisme Islam. Selain konservatisme Islam, dalam pilkada di daerah-daerah, populisme bisa saja menyempit pada isu-isu sentimen agama lainnya. Dengan memperhitungkan jumlah suara, agama mayoritas di suatu daerah mudah diinstrumentalisasi untuk ambisi kekuasaan seorang aktor populis. Di beberapa tempat, isu-isu etnisitas, pribumi dan non-pribumi, insider-outsider, inlanderoutlander, dijadikan sebagai kendaraan memenangkan konstestasi. Singkatnya, populisme kanan yaitu amplifikasi sentimen etnis dan agama mudah menjadi alat seduksi favorit bagi para aktor populis untuk memobilisasi dan mengerahkan suara massa. Apa yang kita bisa pelajari dari populisme kanan di Indonesia ialah bahwa arus pasang globalisasi berusaha dibendung dengan tameng-tameng partikularitas seperti agama dan etnis. Dengan menyodorkan isu-isu etnis dan agama sebagai jalan menghadapi tantangan globalisasi dan mewujudkan keadilan sosial, para aktor dan kandidat populis sebetulnya telah bergeser ke kubu populisme kanan.

Ketiga, memanfaatkan isu gender. Keterwakilan perempuan dalam kontestasi politik di Indonesia masih sangat kurang. Karena itu, seringkali perempuan jarang disebut sebagai aktor populis bila dibandingkan laki-laki. Eva Paron, isteri kedua dari pemimpin populis Argentina, Juan Dominggo Paron, mungkin merupakan seorang perempuan populis pertama di dunia. Fakta bahwa sebagian besar elit populis adalah laki-laki menegaskan citranya sebagai orang di luar politik. Menurut Mudde (2017: 69), posisi gender dalam masyarakat membantu populis perempuan dalam kontestasi politik untuk tampil sebagai "perempuan". Artinya banyak kandidat populis perempuan menekankan diri sebagai "wanita yang baik" seperti didefinisikan oleh budaya. Mereka juga sering menggambarkan diri sebagai ibu atau isteri yang baik. Mereka berusaha tampil "asli" sebagai perempuan untuk 
menciptakan koneksi dan merebut dukungan konstituen atau pemilih dari gender yang sama yaitu perempuan. Yang paling kreatif ialah seorang populis perempuan mampu mengkombinasikan gagasan nasionalisme dan gender. Misalnya mereka akan mengatakan bahwa mereka peduli dengan bangsa atau daerah mereka bagaikan mereka sendiri adalah ibunya, yang merawat bangsa atau daerah itu dengan semangat keibuan. Perlu diperhatikan bahwa gender atau jenis kelamin belum tentu menunjukkan seorang populis perempuan tersebut sudah bersikap feminis. Dalam politik, feminisme menuntut kesetaraan hak bagi perempuan bukan saja melalui wacana tetapi terutama melalui produk undang-undang dan kebijakan publik. Demikian juga, seorang populis lakilaki yang berbicara tentang hak dan keadilan bagi perempuan dalam suatu kampanye politik belum dapat dikatakan sebagai feminis. Menjadi feminis bukan soal gender atau kecerdasan akademis, tapi panggilan etis dalam politik.

\section{Masa Depan Demokrasi}

Berhadapan dengan serangkaian persoalan tersebut, muncul pertanyaan: bagaimana masa depan demokrasi? Masa depan demokrasi tidak mungkin tumbuh di bawah cengkeraman populisme. Populisme kanan, yang anti-pluralis, anti-minoritas dan gemar menabrak prosedur atau mekanisme demokratis, jelas merusak demokrasi. Populisme kanan menjadi musuh demokrasi justru karena dia mensyaratkan beropreasinya logika liberal yang menutup diri terhadap oposisi dan melenyapkan kontradiksi dan pluralitas di bawah kompromi terbatas konsensus rasional. Melalui logika liberal yang anti-oposisi, populisme kanan berusaha membentuk sebuah identitas tunggal dan utuh. Di sini, awasan Laclau amat tepat. Menurutnya, karena sangatlah mustahil menghapus jejakjejak yang partikular dari yang universal, setiap proses identifikasi (termasuk dalam populisme) selalu gagal memproduksi sebuah identitas utuh dan padat (Laclau, 1977: 143).

Dengan kata lain, dalam setiap proses identifikasi, identitas tak pernah "jadi" tapi selalu "men-jadi". Proses identifikasi sejatinya hanya membangkitkan dialektika aspirasi, ketidakpuasan dan ruang kosong. Di dalamnya antagonisme sebagai dialektika tanpa henti deidentifikasi dan reidentifikasi menjadi mungkin. Dengan demikian, proses identifikasi dalam populisme mendukung demokrasi kalau tidak berhasrat membentuk suatu identitas final, melainkan identitas yang berlangsung dalam dialektika tanpa akhir. Mouffe menyebutnya sebagai dialektika antara dekonstruksi dan rekonstruksi identitas. Baik Laclau maupun Mouffe sepakat bahwa energi antagonisme, dekonstruksi dan rekonstruksi identitas ini adalah salah satu kekuatan positip populisme kiri dalam demokrasi.

Jika tidak membelot ke kanan dan menjadi dukungan terhadap oligarki, gagasan populisme kiri yang dijelaskan pada bagian awal tulisan ini sebetulnya dapat memberi sumbangan penting bagi demokrasi. Sebagaimana Mouffe, tugas politik ialah merancang populisme kiri yang merumuskan tuntutan-tuntutan warga yang tidak terakomodasi (Madung, 2018). Energi antagonisme terhadap oligarki adalah sesuatu yang positip bagi demokrasi. Tentu saja, antagonisme ini tidak boleh dibangun di antara warga dan pendatang atau antara kelompok etnis dan agama, melainkan antara warga dan kekuatan-kekuatan politik ekonomi neo-liberal.

Gagasan populisme kiri yang banyak didukung oleh filsuf politik seperti Laclau dan Mouffe selalu ditempatkan dalam konteks demokrasi antagonistik. Sebab supaya gagasan populisme kiri tidak 
gampang berbelok menjadi oportunisme politik yang mengkhianati rakyat, tetapi tetap konsisten dalam mengarahkan perjuangan demi keadilan sosial, dia harus ditempatkan dalam kerangka demokrasi antagonistik. Dalam demokrasi antagonistik, dimensi perjuangan masyarakat melawan kelas-kelas eksploitatif untuk mengadvokasi kesetaraan dan keadilan sosial adalah sebuah prioritas. Demokrasi antagonistik menempatkan berbagai posisi subjek dalam usaha mengartikulasi tuntutan-tuntutan politiknya berdasarkan relasi antagonis dan kontingen (Schaap, 2009: 16). Tentu saja, antagonisme ini tidak bertujuan untuk menegaskan ketidaksetaraan sosial, melainkan untuk menghapus ketidaksetaraan itu.

Saya berkeyakinan, jika populisme kiri konsisten menjadi kekuatan antagonis bagi varian pembusukan ruang publik dan politik oleh the other hari ini, niscaya dia menyokong perwujudan cita-cita demokrasi itu sendiri. Di situ, populisme kiri menjadi "the internal periphery of democracy". Artinya populisme kiri menjadi bagian internal demokrasi yang bergerak pada lingkaran pinggir yaitu the people, dengan melawan dan mengontrol secara konstan elit-elit yang berkuasa, the other, di pusat sistem demokrasi. Populisme kiri juga mengingatkan kita akan "hantu totalitarian" sebenarnya yang sedang mengancam demokrasi hari ini yaitu para elit oligarkis dan neo-liberal yang korup. Dia juga mengingatkan kita bahwa semua masyarakat demokratis modern adalah kompromi antara logika demokratis dan non-demokratis, dan bahwa kontrol terhadap praktik demokrasi liberal secara simultan menjamin serentak membatasi kehendak populis. Di dalam masyarakat global modern, populisme kiri tidak saja membangunkan pertanyaan tentang siapa yang pantas mengisi ruang kosong kekuasaan. Populisme kiri juga mempertanyakan mereka yang meletakkan politik di bawah alasan-alasan teknokratis dan kediktatoran pasar atau neo-liberalisme.

Akhirnya, meletakkan populisme kiri sebagai bagian dari demokrasi antagonistik mensyaratkan satu hal yaitu perjuangan melawan kekuasaan oligarkis dan usaha mewujudkan keadilan sosial harus menjadi perjuangan masyarakat sendiri. Populisme kiri menjadi sebuah pembelotan dan oportunisme politik yang menipu rakyat manakala gerakan ini digantungkan pada seorang yang dianggap karismatik atau penyelamat rakyat. Dalam kerangka demokrasi, perjuangan ini harus menjadi perjuangan rakyat sendiri, yang berarti dilakukan setiap hari, tidak menunggu kontestasi elektoral yang rutin dibuat setiap lima tahun itu. Kita perlu kembali kepada rakyat dalam demokrasi, demos, yaitu warga negara yang kritis, asosiasi-asosiasi, gerakan-gerakan sipil, dan seterusnya yang aktif menyuarakan keadilan setiap saat. Kita bukan rakyat dalam populisme, populus, kerumunan yang mudah ditipu oleh kampanye-kampanye populis para aktor populis. Dengan demikian, masa depan demokrasi tidak bergantung kepada seorang pemimpin populis atau partai populis melainkan kepada rakyat sebagai warga negara itu sendiri.

\section{Penutup}

Sebagai penutup tulisan ini, ada beberapa hal yang menjadi kesimpulan. Pertama, populisme telah menjadi bagian dari perjalanan politik kontemporer baik global, nasional maupun lokal. Hal itu dapat dibuktikan dengan munculnya para pemimpin populis di berbagai negara, termasuk Indonesia, yang mengeksploitasi isu-isu populis dalam rangka mendapatkan suara dukungan publik. Kedua, populisme mengancam demokrasi manakala menjadi alat propaganda politik yang menyemburkan 
narasi-narasi tentang luka rakyat dan perlawanan terhadap kekuasaan oligarkis yang korup, tapi para aktor populis sendiri menjadi bagian dari kekuasaan oligarkis yang dilawannya. Massa menjadi lupa bahwa aktor populis yang mereka dukung adalah bagian dari oportunisme dan kejahatan politik yang mereka lawan. Ketiga, dalam berbagai pengalaman pilkada di Indonesia, populisme kanan yang mengeksploitasi sentimen-sentimen ras dan agama, nasionalisme sempit, ultranasionalis, anti-asing atau anti-minoritas, telah menjadi kendaraan utama untuk merebut dukungan publik. Hal ini jelas menjadi ancaman terberat demokrasi. Kelima, populisme kiri dapat memberikan sumbangan positip bagi demokrasi jika ditempatkan dalam konteks diskursus demokrasi antagonistik. Di sini, perlawanan terhadap oligarki dan perjuangan mewujudkan keadilan sosial harus menjadi perjuangan yang lahir dari kesadaran warga sendiri, bukan atas inisiatif dan kemauan seorang aktor populis.

\section{Daftar Pustaka}

Agustin, Oscar Garcia. 2020. Left-Wing Populism, The Politics of the People. UK: Emerald Publishing.

Albertazzi, Danniele and Duncan McDonell (eds.). 2008. Twenty-First Century Populism, The Spectre of Western Europe Democracy. New York: Palgrave Macmillan.

Bland, Ben. 2020. Man of Contradictions, Joko Widodo and the struggle to remake Indonesia. Australia: Australia Penguin Random Hause.

Hadiz, Vedi R and Richard Robison. 2017. "Competing Populism in Post- authoritarian Indonesia," International Political Science Review, Vol. 38 (4).

Hardiman, F. Budi. 2017. "Gerakan Murka Demorkasi”. Kompas, 2/3/2017, hlm. 6.

Laclau, Ernesto. 1977. Politics and Ideology in Marxist Theory. London: NLB.

Madung, Otto Gusti. 2018. "Populisme dan Krisis Demokrasi," Media Indonesia, $8 / 3 /$.

Mudde, Cas and Cristobal Rovira Kaltwasser. 2017. Populism A Very Schort Introduction. USA: Oxford University Press.

Panizza, Fransisco (ed.). 2005. Populism and the Mirror of Democracy. London-New York: Verso.

Schaap, Andrew (ed.). 2009. Law and Agonistic Politic. UK: University of Exeter. 